\title{
Snowsport Instructors: Their Actual Maximum Speeds, Their Estimation of Maximum Speed and Speed in Slow Zones, and Their Knowledge of Helmet Effectiveness
}

\author{
Tracey J. Dickson and F. Anne Terwiel
}

\begin{abstract}
Snowsport safety strategies include resort and equipment design, trail management, emergency response, and public education. Snowsport instructors are well placed to inform their students about snowsport safety both in the behavior they model and the information they provide. To contribute to the evidence-base of snowsport safety and helmet awareness, this research explores the actual and estimated maximal speeds of ski and snowboard instructors across a normal work-day as well as their knowledge of helmet effectiveness. During winter 2012/13, a convenience sample of 109 instructors was recruited across six resorts in Western Canada and were issued with iPhone $3 \mathrm{~s}$ loaded with the Ski Tracks app. An anonymous questionnaire investigated their prior snowsport experiences, their knowledge of snowsport safety, and their understanding of helmet effectiveness. Results indicated that snowsport instructors: (1) underestimated their maximal speeds by $12 \mathrm{~km} / \mathrm{h}$ on average; (2) overestimated the overall snowsport injury rate as well as the proportion of head injuries; and (3) overestimated the effectiveness of helmets. Based upon these results, if snowsport instructors are to contribute to the knowledge and understanding of the snowsport safety of their students then their own knowledge needs to be developed with regard to helmet effectiveness.
\end{abstract}

Keywords Skiing • Snowboarding $\bullet$ Speed $\bullet$ Slow zones $\bullet$ Helmet effectiveness

\footnotetext{
T.J. Dickson $(\bowtie)$

Research Institute for Sport and Exercise, University of Canberra, Canberra, ACT, Australia e-mail: tracey.dickson@canberra.edu.au
}

\section{F.A. Terwiel}

Faculty of Adventure, Culinary Arts and Tourism, Thompson Rivers University,

Kamloops, BC, Canada

e-mail: aterwiel@tru.ca 


\section{Introduction}

Snowsport safety is a multidisciplinary activity [1] incorporating resort and equipment design [2], trail management [3], emergency response through ski patrol [4], industry codes such as the Alpine Responsibility Code [5], and public education [6]. Snowsport instructors are well placed to contribute to a public education program that addresses key snowsport safety issues. However, in order to capitalize upon their ability to inform the public, snowsport instructors must be knowledgeable about safety-related issues and aware of their own behavior. This research focuses on the knowledge that snowsport instructors have with regard to helmets, their awareness of the speeds at which they travel, and recommendations regarding designated slow zones.

In an effort to enhance snowsport safety, helmets have been promoted as an effective measure to protect against head injuries (e.g., [7-11]). However, recent research has demonstrated that even with increased helmet usage in a non-mandatory environment, head injuries have not been reduced in proportion to the increased usage [12]. It was suggested that this may, in part, be due to an overestimation of the effectiveness of a helmet's protection [13]. Thus, there is debate as to whether helmets should be mandatory [14-16] with evidence that public education may be a more effective safety strategy than mandatory usage [17]. However, for risk or injury prevention communication to be effective it must empower the user to make informed decisions [18].

Further, speed has been associated with the enjoyment of snowsports such as skiing and snowboarding (e.g., [19-21]), but also as a contributing factor to injury (e.g., [22-24]); yet there are only a few studies that have explored actual speeds in snowsport resorts (e.g., [1, 2, 25-31]). Most of this research, as summarized in Table 1, has focused on recreational participants with speeds typically recorded on limited terrain, or a single run, using static radar guns or speed cameras [25, 29-31]. There has been limited work utilizing emerging and more flexible GPS-technology to cover whole-resort behaviors where adults have demonstrated higher speeds [2,

Table 1 Previous English language snowsport speeds research

\begin{tabular}{l|l|l|l|l|l|l|l}
\hline Study & $\begin{array}{l}\text { Data } \\
\text { collection }\end{array}$ & $\begin{array}{l}\text { Participants } \\
(n)\end{array}$ & $\begin{array}{l}\text { Resorts }(n) \\
\text { and country }\end{array}$ & $\begin{array}{l}\text { Terrain } \\
\text { lovered }\end{array}$ & Method & $\begin{array}{l}\text { Range } \\
(\mathrm{km} / \mathrm{h})\end{array}$ & $\begin{array}{l}\text { Mean } \\
(\mathrm{km} / \mathrm{h})\end{array}$ \\
\hline $\begin{array}{l}\text { Shealy } \\
\text { et al. [30] }\end{array}$ & $2002-03$ & 650 & 3 USA & Open run & Radar & $\begin{array}{l}\text { Not } \\
\text { indicated }\end{array}$ & 43.0 \\
\hline $\begin{array}{l}\text { Williams } \\
\text { et al. [31] }\end{array}$ & $\begin{array}{l}\text { Not } \\
\text { indicated }\end{array}$ & 113 & 2 USA & $\begin{array}{l}\text { Terrain } \\
\text { parks and } \\
\text { gladed } \\
\text { areas }\end{array}$ & Radar & $<18-42$ & $\begin{array}{l}\text { Not } \\
\text { indicated }\end{array}$ \\
\hline $\begin{array}{l}\text { Brunner } \\
\text { et al. [25] }\end{array}$ & $2008-09$ & 416 & 4 Austria & $\begin{array}{l}\text { Medium } \\
\text { slope }\end{array}$ & Radar & $\begin{array}{l}\text { Not } \\
\text { indicated }\end{array}$ & 48.2 \\
\hline $\begin{array}{l}\text { Dickson } \\
\text { et al. [2] }\end{array}$ & $\begin{array}{l}2009 \text { and } \\
2010\end{array}$ & 158 pediatric & 2 Australia & $\begin{array}{l}\text { Whole } \\
\text { resort }\end{array}$ & GPS & $\begin{array}{l}6.3- \\
82.2 \mathrm{~km} / \mathrm{h}\end{array}$ & 44.1 \\
\hline $\begin{array}{l}\text { Dickson } \\
\text { et al. [26] }\end{array}$ & $2010-11$ & 102 & 1 Canada & $\begin{array}{l}\text { Whole } \\
\text { resort }\end{array}$ & GPS & $\begin{array}{l}20.2- \\
108.5\end{array}$ & 62.1 \\
\hline
\end{tabular}


26], nor has there been a specific focus on instructors who may act as safety role models and educators.

A common finding from all of this speeds research (Table 1) that is relevant for snowsport safety is that most participants, young and old, beginner through expert, regularly exceed the flat impact test standards for snowsport helmets which are in the range of $20-23 \mathrm{~km} / \mathrm{h}[2,32-35]$. It has been demonstrated that people regularly exceed their own recommended speeds for slow zones [26]. Slow zones are typically identified by prominent signs on slopes and markings on trail maps, and include learning areas, areas reserved for children, trail junctions, and busier runs. Those signs, according to the Alpine Responsibility Code, should be obeyed [5], but there is lack of understanding as to what "slow" means [26]. From a risk management or snowsport safety perspective together these may be problematic when arguing for slow zone regulation and mandatory helmet usage and may explain research that refers to mitigation of injury rather than prevention [36-39].

To contribute to the evidence-base of snowsport safety, speed regulation, and helmet awareness, with respect to professional snowsport instructors, this research explores:

1. The actual and estimated maximum on-snow speeds of professional snowsport instructors in six mid-sized Western Canada resorts during a normal work-day

2. Recommendations for speeds in designated slow zones

3. Their knowledge and understanding of snowsport helmet effectiveness

4. The differences that exist between the characteristics of helmet wearers and nonhelmet wearers and their on-snow behaviors

The broader context of this research is Western Canadian snowsport where the governing bodies of ski and snowboard instructors are the Canadian Ski Instructors Alliance (CSIA), and the Canadian Association of Snowboard Instructors (CASI). They are responsible for instructor training, certification, and ongoing education, with education committees responsible for developing content and materials that enable and support instructor training, certification, and teaching ([40], Sec 1.3).

The mission statement of the CSIA is that the CSIA "sets the standard for the profession of ski teaching" ([40], 1.2). Their manual provides a detailed Code of Ethics to be followed, and under the heading Responsible Teaching, demands that the activities of members will be done safely and with the best interests of all participants in mind ([40], 1.4). The manual reinforces the concept of Duty of Care, taught to all instructors in every certification course, encouraging them to act as a prudent parent would act, and to conduct themselves as knowledgeable, responsible, and vigilant guides, acting with strict adherence to the Alpine Responsibility Code ([40], 1.10).

Regarding helmet use, "The CSIA supports its members, staff and partners and their choices on helmet use while skiing ... The CSIA encourages informed helmet use" ([40], 1.10). Currently, all CSIA Course Conductors wear helmets while conducting certification courses; however, course participants are not mandated to wear helmets. At the time of this research, helmet wearing was not mandatory for snowsport instructors in western Canada 
With respect to speed, the CSIA does not have a stated public position. In instructor certification courses, participants are taught to use "appropriate" speed and terrain, suitable to the skill of the guest and the goals of the lesson [41]. The CSIA promotes the Alpine Responsibility Code [5] where the first item relates to speed: "Always stay in control. You must be able to stop, or avoid other people or objects."

\section{Method}

In order to explore the on-snow work-day behavior of snowsport instructors and their knowledge and understanding of key snowsport safety issues, a convenience sample of snowsport instructors was recruited across six resorts in Western Canada during the 2012/13 season. Data was collected at each resort over two consecutive days. Instructors were approached at their morning meetings and briefed on the research; up to ten instructors volunteered each day to participate. Speed, distance, and duration over the day were recorded using the "Ski Tracks" app (http://www. corecoders.com/applications/ski-tracks/) on ten iPhone $3 \mathrm{~s}$. Ski Tracks is a GPSbased application that does not require WiFi or Phone connections. This smartphone application was chosen to apply a more affordable and publically accessible GPSbased technology than in previous research $[1,42]$. At the time of this research, Ski Tracks was the world's most downloaded ski application. Ski Tracks is battery efficient (up to $14 \mathrm{~h}$ of track recording), runs in the background, is simple to operate, does not require a SIM card and is ski/snowboard specific. Readouts include maximum speed, average speed, ski distance (ascent and descent), accumulated vertical distance, number of runs, slope angle, and time duration.

Participants completed an anonymous questionnaire exploring: demographic information including age range, previous snowsport experience across four snowsport disciplines: snowboarding, alpine skiing, telemarking, and cross-country skiing (no experience, 1 day, 2-6 days, 7-13 days, 14-27 days, 4-8 weeks, $>8$ weeks); history of serious snowsport injury (i.e., concussion, fracture, dislocation) in each snowsport discipline (no injury, 1, 2, 3, 4, 5, 6, or more); how fast they believe that skiers should ski in slow zones (open question); perception of their own maximum speed (open question) and distance travelled that day (open question); and they were asked to estimate the maximum speed at which a snowsport helmet is effective (open question). To explore knowledge of snowsport risks, participants were asked, 'If there are 1000 people on the slopes today, how many people do you think will be injured? $(<1,1-5,6-10,11-15,16-20$, more than 20); and 'Of all snowsport injuries, what percentage do you think are head injuries? (open question). Current GPS use was also explored to track awareness and changes in uptake.

With the initial part of the questionnaire completed, and data-recording devices fitted, instructors undertook their normal day's instructional activity. The full variety of lesson types were represented, with guests ranging from beginner through 
advanced and from very young children through to older adults. Instructors completed the reflective portion of the questionnaire at the end of their work-day. No data was collected on client profiles.

Data was entered into SPSS v21 for analysis and included descriptive statistics to summarize the data (e.g., mean and standard deviation, as well as mode for speeds in slow zones) and between group differences. Chi-squared tests were used to assess differences between groups (gender, age, and activity) regarding GPS use and helmet use; a paired sample $t$-test was used to compare instructors' estimated and actual maximum speeds and independent-samples $t$-tests assessed differences between groups (gender, age, and helmet use) regarding actual maximum speeds, where ages were recoded into groups for further analysis. A p-value of 0.05 was used to determine significance.

\section{Results}

In the following results, the resorts have been de-identified to protect their anonymity, as was agreed to at the outset of the study.

\subsection{Respondents: Demographics, Serious Injuries, and Risk Awareness}

There were 109 participants from the six resorts over 12 days of data collection, $36 \%$ were females, and $96 \%$ had self-reported skill levels of advanced/expert; 78\% were ski instructors and $22 \%$ snowboard instructors, with $75 \%$ wearing helmets.

The age range was $19-67$ years $(\bar{x}=32.5$ years, $\mathrm{SD}=11.7)$, with the largest group being 25-34 years (Table 2). The older age groups (45 years and over) had the lowest rate of helmet use (67\%), while the youngest (15-24 years) had the highest rate of helmet use (84\%).

Outside this study, GPS-enabled equipment such as watches and Smartphone apps was used by $31 \%$ of respondents. Pearson Chi-squared analyses demonstrated

Table 2 A comparison of snowsport helmet use according to age groups

\begin{tabular}{l|l|l|l}
\hline & No helmet & Helmet worn & Total \\
\hline $15-24$ years & $5(16 \%)$ & $27(84 \%)$ & $32(30 \%)$ \\
\hline $25-34$ years & $12(29 \%)$ & $29(71 \%)$ & $41(38 \%)$ \\
\hline $35-44$ years & $3(23 \%)$ & $10(77 \%)$ & $13(12 \%)$ \\
\hline $45-54$ years & $5(33 \%)$ & $10(67 \%)$ & $15(14 \%)$ \\
\hline 55 and over & $2(33 \%)$ & $4(67 \%)$ & $6(6 \%)$ \\
\hline & $27(25 \%)$ & $80(75 \%)$ & 107 \\
\hline Missing & & & 2 \\
\hline
\end{tabular}


that there was no significant difference between GPS use by females and males $(p=0.81)$, younger and older instructors $(p=0.96)$, nor between skiers and snowboarders $(p=0.32)$.

To consider risk-awareness participants were asked if they had experienced a serious snowsport injury, defined as being a concussion, fracture, or dislocation. Most alpine ski instructors had experienced a serious injury while skiing (67\%), which was the same for snowboard instructors who had experienced a serious injury while snowboarding. When estimating snowsport injury rates and proportion of head injuries, just $32.7 \%$ of instructors correctly estimated the injury rate at between 1-5 injuries per 1000 skier-days, $19.6 \%$ believed the injury rate was 16 or more per 1000 skier-days. Others indicated: 0 (0.9\%), 6-10 (27.1\%), 11-15 $(19.6 \%)$. Estimates of the proportion of head injuries ranged from 0 to $80 \%$ $(\bar{x}=22.0 \%, \mathrm{SD}=17.6), 79.4 \%$ estimated that $10 \%$ or more of injuries are to the head, the remainder indicated: nil (2.8\%), 1 (0.9\%), $2(5.6 \%), 4(0.9 \%), 5(10.3 \%)$, and $8(0.9 \%)$.

\subsection{Duration, Distance Travelled, and Maximum Speeds}

Total skiing/boarding time logged was $665 \mathrm{~h}(2: 49-8: 50 \mathrm{~h}, \bar{x}=6: 06 \mathrm{~h}, \mathrm{SD}=1: 24 \mathrm{~h})$, covering $4389.2 \mathrm{~km}$ ( $\bar{x}=6.6 \mathrm{~km}$ travelled per hour). The number of runs taken ranged from 1 to 25 , with an average of nine runs per work-day (SD $=4.8$ ). Maximum-recorded speeds ranged from $25.9-110.6 \mathrm{~km} / \mathrm{h}(\bar{x}=64.7 \mathrm{~km} / \mathrm{h}$, $\mathrm{SD}=17.4)$. Estimates of their maximum speeds ranged from 10 to $140 \mathrm{~km} / \mathrm{h}$ $(\bar{x}=53.0 \mathrm{~km} / \mathrm{h}, \mathrm{SD}=25.3)$. A paired sample $t$-test of the estimated and actual maximum speeds was significant $(t(99)=5.92, p<0.001)$ with instructors underestimating their maximum speeds by an average of $12 \mathrm{~km} / \mathrm{h}$.

Male instructors travelled faster and further than females, with a $13.6 \mathrm{~km} / \mathrm{h}$ difference in mean maximum speeds (69.6 versus $56.0 \mathrm{~km} / \mathrm{h}$ ), and a $6.4 \mathrm{~km}$ difference in mean distance travelled ( 23.2 versus $16.8 \mathrm{~km}$ ). Younger instructors $(<25$ years) travelled less distance and had lower mean maximum speeds than older instructors (i.e., 25 years plus). An independent sample t-test analysis was conducted to compare the actual maximum speeds for females and males, as well as younger ( $<25$ years) and older ( 25 years plus) instructors. There was a significant difference in the actual maximum speeds for females $(\bar{x}=56.0 \mathrm{~km} / \mathrm{h}, \mathrm{SD}=15.87)$ and male instructors $(\bar{x}=69.6 \mathrm{~km} / \mathrm{h}, \mathrm{SD}=16.54 ; t(105)=4.15, p=<0.01)$ and also for younger $(\bar{x}=59.1 \mathrm{~km} / \mathrm{h}, \mathrm{SD}=18.80)$ and older instructors $(\bar{x}=66.7 \mathrm{~km} / \mathrm{h}$, $\mathrm{SD}=16.43 ; t(105)=2.09, p=0.04)$. For mean distance travelled, there was a significant difference between female $(\bar{x}=28.6 \mathrm{~km}, \mathrm{SD}=12.2)$ and male $(\bar{x}=46.8 \mathrm{~km}, \mathrm{SD}=50.4 ; t(105)=2.222, p=0.03)$ instructors, and between younger $(\bar{x}=27.7 \mathrm{~km}, \mathrm{SD}=10.5)$ and older $(\bar{x}=45.2 \mathrm{~km}, \mathrm{SD}=48.4$; $t(105)=2.0 .28, p=0.045)$ instructors. An independent-samples t-test analysis did not reveal a significant difference between helmet wearers $(\bar{x}=64.8 \mathrm{~km} / \mathrm{h}$, $\mathrm{SD}=18.3)$ and non-helmet wearers $(\bar{x}=64.4 \mathrm{~km} / \mathrm{h}, \mathrm{SD}=14.8 ; t(107)=2.115$, 
$p=0.91)$ nor for GPS users $(\bar{x}=63.1 \mathrm{~km} / \mathrm{h}, \mathrm{SD}=16.4)$ and non-users $(\bar{x}$ $=65.1 \mathrm{~km} / \mathrm{h}, \mathrm{SD}=18.3 ; t(100)=0.53, p=0.60)$.

\subsection{Slow Zone Recommendations}

The range in instructor-recommended maximum speed for slow zones was between 2 and $62 \mathrm{~km} / \mathrm{h}(\bar{x}=20.8 \mathrm{~km} / \mathrm{h}, \mathrm{SD}=11.9$, mode $=20 \mathrm{~km} / \mathrm{h})$, with an almost $5 \mathrm{~km} / \mathrm{h}$ difference in the recommendations between male $(\bar{x}=22.6 \mathrm{~km} / \mathrm{h}$, $\mathrm{SD}=12.8)$ and female $(\bar{x}=17.8 \mathrm{~km} / \mathrm{h}, \mathrm{SD}=9.8 ; t(101)=1.98, p=0.051)$ instructors though not statistically significant. Though there was nearly $3 \mathrm{~km} / \mathrm{h}$ difference in the recommendations of older $(\bar{x}=21.6 \mathrm{~km} / \mathrm{h}, \mathrm{SD}=12.5)$ and younger instructors $(\bar{x}=18.8 \mathrm{~km} / \mathrm{h}, \mathrm{SD}=10.6 ; t(101)=1.10, p=0.28)$, this was not statistically significant either. An independent-samples $t$-test was conducted to compare the recommended maximum speeds in slow zones between helmet wearers and non-helmet wearers. There was no significant difference in estimates for helmet wearers ( $\bar{x}=19.9 \mathrm{~km} / \mathrm{h}, \mathrm{SD}=10.7)$, and non-helmet wearers $(\bar{x}=23.3 \mathrm{~km} / \mathrm{h}, \mathrm{SD}=15.2 ; t(103)=1.05, p=0.30)$, nor for GPS users $(\bar{x}$ $=18.1 \mathrm{~km} / \mathrm{h}, \mathrm{SD}=9.3)$ a non-users $(\bar{x}=21.5 \mathrm{~km} / \mathrm{h}, \mathrm{SD}=12.9 t(96)=1.32$, $p=0.19)$.

\subsection{Helmet Effectiveness}

Helmets were worn by $75 \%$ of respondents that day, with the estimates for the maximum speed to which helmets are effective ranging from 0 to $150 \mathrm{~km} / \mathrm{h}$ $(\bar{x}=54.1 \mathrm{~km} / \mathrm{h}, \mathrm{SD}=29.5)$. An independent-samples $t$-test was conducted to compare the estimated maximum speeds to which helmets are effective between helmet wearers and non-helmet wearers. There was no significant difference in estimates for helmet wearers $(\bar{x}=54.3 \mathrm{~km} / \mathrm{h}, \mathrm{SD}=27.5)$, and non-helmet wearers $(\bar{x}=53.7 \mathrm{~km} / \mathrm{h}, \mathrm{SD}=36.5 ; t(90)=0.82, p=0.94)$. Those with higher maximum recorded speeds believed that their helmets were effective to higher speeds.

\subsection{Characteristics of Helmet Wearers Vs. Non-Helmet Wearers}

The only between group difference noted between helmet wearers and non-helmet wearers was for alpine skiing vs. snowboarding $(1, n=109)=0.04$ (Table 3). Chisquared tests indicated there was no significant difference for gender (1, $n=107)=0.08$, nor age groups $(1, n=107)=0.14$. 
Table 3 Characteristics of helmet wearers and non-helmet wearers

\begin{tabular}{|c|c|c|c|c|}
\hline & No helmet & Helmet worn & Total & $p^{*}$ \\
\hline \multicolumn{5}{|l|}{ Gender } \\
\hline Female & $6(15 \%)$ & $33(85 \%)$ & 39 & 0.08 \\
\hline Male & $21(31 \%)$ & $47(69 \%)$ & 68 & \\
\hline Total & $27(25 \%)$ & $80(75 \%)$ & 107 & \\
\hline \multicolumn{5}{|c|}{ Age groups: $<25,25+$} \\
\hline$<25$ years & $5(16 \%)$ & $27(84 \%)$ & 32 & 0.14 \\
\hline 25 years plus & $22(29 \%)$ & $53(71 \%)$ & 75 & \\
\hline Total & $27(25 \%)$ & $80(75 \%)$ & 107 & \\
\hline \multicolumn{5}{|c|}{ Main Snowsport Activity "Today" } \\
\hline Alpine skiing & $25(29 \%)$ & $60(71 \%)$ & 85 & 0.04 \\
\hline Snowboarding & $2(8 \%)$ & $22(92 \%)$ & 24 & \\
\hline Total & $27(25 \%)$ & $82(75 \%)$ & 109 & \\
\hline
\end{tabular}

*Chi-squared

\section{Discussion}

This novel research was able to utilize new smartphone technology that is expanding the repertoire of data collection methods of researchers. The fact that Ski tracks is free, is purposely designed for snowsport, does not require phone coverage or network access, and is able to be used around the world, was beneficial to this project.

To be effective, a public education campaign must be based upon accurate data, conveyed by trained and knowledgeable people [43]. Snowsport instructors are one information conduit to participants who are new to snowsports, and to those looking to improve their snowsport skills. This research was undertaken in an effort to assess the knowledge and behaviors of these potential snowsport safety educators by investigating their: estimated and actual maximum on-snow; recommended speeds in designated slow zones, knowledge of snowsport helmets; and to determine if there were differences between helmet wearers and non-helmet wearers, so that we might gain some insight into the information these experts may need to accurately and effectively inform the snowsport public.

Respondents were from across the age spectrum of resort workers, with mostly male respondents. Notable is that in this non-mandatory period, $75 \%$ of participating instructors were wearing helmets.

With a range of $26-110 \mathrm{~km} / \mathrm{h}$ all respondents achieved maximum speeds that exceed the test standards of snowsport helmets (e.g., [32, 34]). The lack of difference in maximum recorded speeds between helmet wearers and non-helmet wearers reflects previous research [44], but contrasts with earlier research that did see a difference [30], which may reflect normalizing of behaviors as helmet wearing becomes more common, or it could reflect cultural differences in research sites.

It is not possible to speculate on whether differences in speeds and distance travelled between males and females and older and younger instructors lie in the instructors themselves, or in the skill level of guests with whom individual instructors were 
working. Regarding estimation of speeds, female instructors underestimated their actual maximum speed by $16.9 \mathrm{~km} / \mathrm{h}$, while males only underestimated maximum speeds by $8 \mathrm{~km} / \mathrm{h}$. However, of the $31 \%$ of instructors who reported GPS-enabled equipment already in use, an independent-samples $t$-test indicated that there was no significant difference in their means for maximum speeds, estimated maximum speeds, or recommended speeds in slow zones. That said, Mobile Applications (apps) that measure speed, distance, vertical accumulated, etc. may be changing the on-hill behavior of snowsport instructors and the general public. Now that these apps are ubiquitous, research is needed to ascertain whether this is the case, and if so, is this a safety management problem. (http://www.banfflakelouise.com/Media-Relations/News-Releases/ RockiesReplay-Allows-Skiers-and-Snowboarders-to-Shred-with-Cred-at-Banff-National-Park-Ski-Resorts).

Previous research on slow zone recommendations in a study of a single resort [26] revealed a range of 5-60 km/h with a slightly higher mean of $23.8 \mathrm{~km} / \mathrm{h}$ and a higher mode of $30 \mathrm{~km} / \mathrm{h}$. Experts in this previous research had a range of $10-50 \mathrm{~km} . \mathrm{h}$ and much higher mean of $33.4 \mathrm{~m} / \mathrm{h}$. This survey of instructors across six resorts reveals a much more conservative recommendation for slow zones than the broader public at just one resort.

With regard to estimates of the speeds to which helmets are effective, there was a remarkable $150 \mathrm{~km} / \mathrm{h}$ range, an indication that, at the time of this research, information about the speed to which helmets are tested to meet the helmet's limited performance requirements had failed to reach this group of instructors. The mean of $54 \mathrm{~km} / \mathrm{h}$ across the six resorts is the same as previous research with instructors at a single resort [13]. When considering speed and helmet effectiveness it is worth noting that the kinetic energy at $65 \mathrm{~km} / \mathrm{h}$ is nearly eight times higher than at $23 \mathrm{~km} / \mathrm{h} \mathrm{[30]} \mathrm{which} \mathrm{will} \mathrm{impact} \mathrm{the} \mathrm{ability} \mathrm{of} \mathrm{a} \mathrm{helmet} \mathrm{to} \mathrm{reduce}$ head accelerations as per the standards. The wide range regarding speeds to which helmets are expected to be effective indicates a knowledge gap between snowsport instructors and the helmet industry. Commensurate with a risk communication approach it is necessary for instructors to be educated about the design and use of helmets relative to the speeds achieved in normal snowsport behaviors, in order to be able to provide accurate information to their students as part of a broader snowsport safety strategy. The current mandate to wear helmets while working points to further research to ensure that helmets are being used effectively such as looking at how instructors purchase their helmets (used versus new), how the helmets fit, how they are worn, and in particular, how they are cared for [45].

The higher than average rate of serious injury reported may reflect the higher exposure levels of instructors compared to the average participant who only participates in snowsports 10 days a year [46]. Some instructors are working back-to-back winters (teaching in the northern hemisphere December through April and in the southern hemisphere June through September), effectively doubling their yearly exposure. Having been exposed to or perceiving more serious injuries than the norm may have contributed to their overestimation of the risk of injury in the broader public, but does not appear to have impacted their behaviors such as maximum recorded speeds. Nearly one-third correctly estimated snowsport injuries to be in 
the range of 1-5 injuries per 1000 skier visits, at the time of the research it was closer to 2 per 1000 skier visits in Western Canada [12]; most overestimated the head injury rate which was close to $9 \%$ of reported injuries at the time [12]. This may be a result of the increased interest in head injuries, particularly concussions, across a range of sports.

While snowsport instructors are well positioned to support a public education campaign, this research has demonstrated that neither the CSIA nor CASI provide information through their manuals to their members upon which they can make an informed decision about helmet use or the effectiveness of helmets. This raises a further question as to who could, or should, help provide relevant information about helmet effectiveness. Further, the research has shown that for the sample here, their knowledge of snowsport risks, helmet effectiveness, expectations about behaviors in slow zones, and their ability to estimate their speeds is problematic if they are to be central to a public education campaign that will clarify snowsport safety for the broader public.

\section{Limitations}

Instructors were fitted with the GPS-logging device at the beginning of their work-day and turned the devices in at the end of the day. We are unable to determine whether instructors were working with guests every minute that the devices were recording, or whether they may have gone skiing or boarding on their own between or after lessons. The research was conducted during the height of the Western Canadian snowsport season, during which time most instructors are fully utilized, however there is no way to confirm that all data collected represented time with students. All instructors were in uniform for the duration of the recording time, so whether with students or not, as they were still in uniform they were in the public eye.

While this research was undertaken to try to understand the knowledge levels of ski and snowboard instructors in general, the relatively small sample size and the convenience sample limits the generalizability to a larger population.

Speed analysis, in the form of maximum speed rather that mean speed, was the unit of analysis in this research. This is because the Ski Tracks application measures speed from the time it begins recording until it is shut off. That means Ski Tracks measures speed while standing still, walking, riding the chair lift, etc. With Ski Tracks the only reliable measure of speed while sliding downhill is maximum speed, as maximum speed cannot occur in situations other than skiing or snowboarding while on-hill during the work-day.

Finally, while the focus on speeds was downplayed it was possible that instructors were aware that speed data was being collected, and as such, may have modified their behavior, as per the Hawthorne Effect [47]. 


\section{Conclusion}

Consistent with previous research on recreational participants, during this novel research that utilized a smartphone application, snowsport instructors: (1) underestimated the speeds they travelled by an average of $12 \mathrm{~km} / \mathrm{h}$, (2) recommended lower slow zone speeds than recreational participants, (3) overestimated the speeds at which helmets may be effective, as indicated by industry standards, and (4) overestimated the injury risk in snowsports.

Finally, it has been proposed that education programs are the best way to inform both instructors and the general public about safe behavior within resorts, involving both the use of personal protective equipment and personal and group behavior. Research is necessary to determine if this is, in fact, the case in a snowsport environment.

\section{References}

1. Dickson TJ, Trathen S, Waddington G, Terwiel FA, Baltis D (2016b) A human factors approach to snowsport safety: novel research on pediatric participants' behaviors and head injury risk. Appl Ergon 53(Part A):79-86. doi:10.1016/j.apergo.2015.08.006

2. Dickson TJ, Trathen S, Waddington GS (2015) Speeds of pediatric snowsport participants: insights for injury prevention strategies. In: Johnson RJ, Shealy JE, Greenwald RM (eds) Skiing trauma and safety: 20th volume, STP1582 ASTM international, West Conshohocken, PA, pp 141-149

3. Bergstrom KA, Ekeland A (2004) Effect of trail design and grooming on the incidence of injuries at alpine ski areas. Br J Sports Med 38(3):264-268

4. Kuepper T, Steffgen J, Gore C, Perren B, Zahnd P, Gore R (2002) Qualified rescue by ski patrols-safety for the skier. Int J Sports Med 23(7):524-529

5. Canada West Ski Areas Association (2016) Policy-Alpine Responsibility Code. http://www. cwsaa.org/policy/alpine-responsibility-code.html. Accessed 19 Jan 2016

6. Levy AS, Hawkes AP, Rossie GV (2007) Helmets for skiers and snowboarders: an injury prevention program. Health Promot Pract 8(3):257-265

7. Cusimano MD, Kwok J (2010) The effectiveness of helmet wear in skiers and snowboarders: a systematic review. Br J Sports Med 44:781-786. doi:10.1136/bjsm.2009.070573

8. Hagel BE, Pless IB, Goulet C, Platt RW, Robitaille Y (2005) Effectiveness of helmets in skiers and snowboarders: case-control and case crossover study. Br Med J 330(7486):281. doi: $10.1136 / \mathrm{bmj} .38314 .480035 .7 \mathrm{C}$

9. Haider AH, Saleem T, Bilaniuk JW, Barraco RD, Committee obotEAftSoTICP (2012) An evidence-based review: efficacy of safety helmets in the reduction of head injuries in recreational skiers and snowboarders. J Trauma Acute Care Surg 73(5):1340-1347. 1310.1097/ TA.1340b1013e318270bbca

10. Jung C, Zweckberger K, Schick U, Unterberg A (2011) Helmet use in winter sport activitiesattitude and opinion of neurosurgeons and non-traumatic-brain-injury-educated persons. Acta Neurochir 153(1):101-106. doi:10.1007/s00701-010-0704-8

11. Russell K, Christie J, Hagel BE (2010) The effect of helmets on the risk of head and neck injuries among skiers and snowboarders: a meta-analysis. Can Med Assoc J 182(4):333-340

12. Dickson TJ, Trathen S, Terwiel FA, Waddington G, Adams R (2016a) Head injury trends and helmet use in skiers and snowboarders in Western Canada, 2008-09 to 2012-13: an ecological study. Scand J Med Sci Sport. Doi:10.1111/sms.12642 
13. Terwiel FA, Dickson TJ (2015) Helmets: what do snowsport instructors and guests know and expect? In: Johnson RJ, Shealy JE, Greenwald RM (eds) Skiing trauma and safety: 20th volume, STP 1582. ASTM International, West Conshohocken, PA, pp 3-21. doi:10.1520/ STP158220140008

14. Bussewitz C (2010) California considers mandatory ski helmet laws. USA Today

15. CBC News (2012) Ski helmets lack mandatory Canadian safety rules: Canadian Standards Association alpine helmet guidelines. Under review

16. Ruedl G, Kopp M, Burtscher M (2010a) Editorial: mandatory ski helmets? Can Med Assoc J 182(9):942

17. Ruedl G, Kopp M, Burtscher M (2012b) Editorial: is ski helmet legislation more effective than education? Br J Sports Med 46(16):1091-1092. doi:10.1136/bjsports-2012-091374

18. Covello V, Sandman PM (2001) Risk communication: evolution and revolution. In: Wolbarst A (ed) Solutions to an environment in peril. John Hopkins University Press, Baltimore, pp 164-178

19. Brandauer T, Senner V, Woitschell J (2010) Speed and ability as modulating factors of the flow experience while skiing on prepared slopes. In: Müller E, Lindinger S, Stöggl T, Pfusterschmeid J (eds) Science and skiing V. Meyer \& Meyer Sport, Maidenhead, pp 85-93

20. Dickson TJ, Terwiel FA (2013) Supervising snowsport activities: a reflection upon legislation, policies, guidelines and practice. Aust J Outdoor Educ 16(2):24-41

21. Ruedl G, Abart M, Ledochowski L, Burtscher M, Kopp M (2012a) Self reported risk taking and risk compensation in skiers and snowboarders are associated with sensation seeking. Accid Anal Prev 48(0):292-296. doi:10.1016/j.aap.2012.01.031

22. Chaze B, McDonald P (2009) Head injuries in winter sports: Downhill skiing, snowboarding, sledding, snowmobiling, ice skating and ice hockey. Phys Med Rehabil Clin N Am 20(1):287-293

23. Franz T, Hasler RM, Benneker L, Zimmermann H, Siebenrock KA, Exadaktylos AK (2008) Severe spinal injuries in alpine skiing and snowboarding: a 6-year review of a tertiary trauma centre for the Bernese Alps ski resorts, Switzerland. Br J Sports Med 42(1):55-58. doi:10.1136/ bjsm.2007.038166

24. Spörri J, Kröll J, Amesberger G, Blake OM, Müller E (2012) Perceived key injury risk factors in World Cup alpine ski racing - an explorative qualitative study with expert stakeholders. $\mathrm{Br}$ J Sports Med. bjsports-2012-091048

25. Brunner F, Ruedl G, Kopp M, Burtscher M (2015) Factors associated with the perception of speed among recreational skiers. PLoS One 10(6):e0132002

26. Dickson TJ, Terwiel FA, Waddington GS, Trathen S (2012) Easiest routes and slow zones: how fast do I go?: speeds and distances of recreational and expert snowsport participants. In: Johnson RJ, Shealy JE, Greenwald RM, Scher I (eds) STP 1553 skiing trauma and safety: 19th volume. ASTM International, West Conshohocken, PA, pp 184-197. doi:10.1520/STP104413

27. Dickson TJ, Waddington G, Trathen S, Baltis D, Adams R (2013) Technology applications to enhance understanding of real-time snowsport head accelerations. Procedia Eng 60(0):220 225. doi:10.1016/j.proeng.2013.07.079

28. Ruedl G, Brunner F, Woldrich T, Faulhaber M, Kopp M, Nachbauer W, Burtscher M (2013) Factors associated with the ability to estimate actual speeds in recreational alpine skiers. Wilderness Environ Med 24(2):118-123. doi:10.1016/j.wem.2012.11.021

29. Scher I, Richards D, Carhart M, Thomas R, Hurlen N, Lam T (2008) Pediatric head and neck injuries in snow sports: evaluating the influence of helmets. J ASTM Int 5(4):91-100

30. Shealy JE, Ettlinger CF, Johnson RJ (2005) How fast do winter sports participants travel on alpine slopes? J ASTM Int 2(7):12092-12098

31. Williams R, Delaney T, Nelson E, Gratton J, Laurent J, Heath B (2007) Speeds associated with skiing and snowboarding. Wilderness Environ Med 18(2):102-105

32. ASTM International (2000) F2040 Standard specification for helmets used for recreational snow sports. ASTM International, West Conshohocken, PA

33. Canadian Standards Association (2009) CSA Z263.1-08 Recreational alpine skiing and snowboarding helmets. Ontario 
34. European Committee for Standardization (1996) EN 1077:1996 Helmets for alpine skiers. European Committee for Standardization, Brussels.

35. Snell Memorial Foundation (1998) 1998 Standard for Protective Headgear RS-98 For Recreational Skiing and Snowboarding. http://www.smf.org/standards/ski/rs98std.html. Accessed 18th May 2009

36. Editor (2014) Families approve of increased slow zone safety. The Whistler News

37. Fidel S (2010) Reckless skier hurts 6-year-old girl. Deseret News

38. Scher I, Richards D, Carhart M (2006) Head injury in snowboarding: Evaluating the protective role of helmets. J ASTM Int 3(4):14203-14209

39. Shealy JE, Johnson RJ, Ettlinger CF, Scher I (2015) Role of helmets in mitigation of head injuries: epidemiologic study of head injuries to skiers. In: Johnson RJ, Shealy JE, Greenwald RM (eds) Skiing trauma and safety: 20th volume, STP1582 ASTM international, West Conshohocken, PA, pp 22-36

40. Canadian Ski Instructor's Alliance (2011) Canadian Ski teaching. Canadian Ski Instructor's Alliance, Montreal, QB

41. Canadian Ski Instructor's Alliance (2013) Canadian Ski teaching

42. Dickson TJ, Terwiel FA, Waddington G, Trathen S (2011) Evaluation of the use of a GPS datalogging device in a snowsport environment. Procedia Eng 13:470-475. doi:10.1016/j. proeng.2011.05.116

43. Poulos R, Donaldson A, Finch C (2010) Towards evidence-informed sports safety policy for New South Wales, Australia: assessing the readiness of the sector. Inj Prev 16(2):127-131

44. Ruedl G, Pocecco E, Sommersacher R, Gatterer H, Kopp M, Nachbauer W, Burtscher M (2010b) Factors associated with self-reported risk-taking behaviour on ski slopes. Br J Sports Med 44(3):204-206. doi:10.1136/bjsm.2009.066779

45. Shealy JE, Stepan L (2013) Head Injury and Helmets in Skiing \& Boarding. Paper presented at the Can West Ski Areas Association Spring Meeting, 6th-9th May, Kelowna, BC, Canada

46. Canadian Ski Council (2011) 2010-2011 Canadian Skier and Snowboarder Facts and Stats

47. Landsberger HA (1958) Hawthorne revisited: Management and the worker: its critics, and developments in human relations in industry. Cornell Studies Series, vol 9. Cornell University, New York

Open Access This chapter is distributed under the terms of the Creative Commons AttributionNoncommercial 2.5 License (http://creativecommons.org/licenses/by-nc/2.5/) which permits any noncommercial use, distribution, and reproduction in any medium, provided the original author(s) and source are credited.

The images or other third party material in this chapter are included in the work's Creative Commons license, unless indicated otherwise in the credit line; if such material is not included in the work's Creative Commons license and the respective action is not permitted by statutory regulation, users will need to obtain permission from the license holder to duplicate, adapt or reproduce the material. 